\section{H.O. Lange-Prisen 2003}

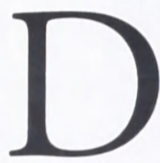
irektør ved Det Kongelige Bibliotek, Erland Kolding Nielsen, bød 16. september på vegne af G.E.C. Gad A/S og Det Kongelige Bibliotek publikum velkommen til uddeling af H.O. Lange-Prisen, opkaldt efter Det Kongelige Biblioteks navnkundige overbibliotekar 1901-1924.

H.O. Lange-Prisen, der er en forskningsformidlingspris, blev givet til professor, lic.phil. Anne-Marie Mai for hovedredaktion af 4. udgaven af Danske digtere i det 20. århundrede, udgivet på Gads Forlag og udkommet i tre bind i tidsrummet 20002002. Priskomiteen, der har indstillet tre sideordnede prismodtagerforslag til Det Kongelige Biblioteks og G.E.C. Gads direktører, gav i forbindelse med indstilling af vinderforslaget følgende begrundelse: "Værket er en formidlingsmæssig bedrift, dertil et forskningsbaseret standardværk med appel til både fagfolk og den alment interesserede læser. Redaktøren har tillige generelt markeret sig som forskningsformidler både inden for det litterære univers og i den bredere offentlighed".

\section{H.O. Lange-Prisen blev i 2003 uddelt for} tredje gang.

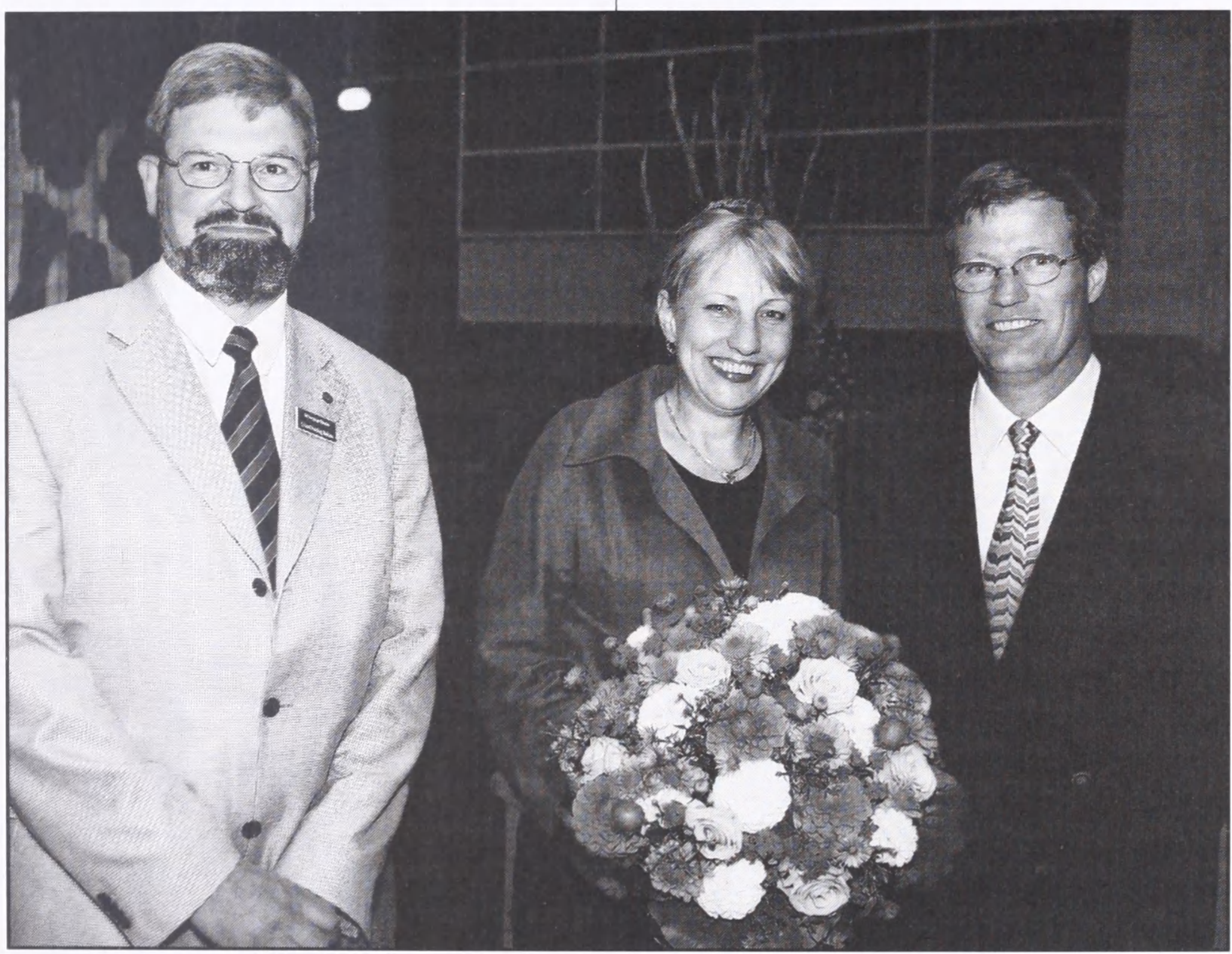

Prisuddeling i Dronningesalen på Det Kongelige Bibliotek. Fra venstre: Direktor ved Det Kongelige Bibliotek, Erland Kolding Nielsen, prisvinder professor lic.phil. Anne-Marie Mai og adm. direktor Soren Lang, G.E. C. Gad A/S. (Det Kongelige Bibliotek). 


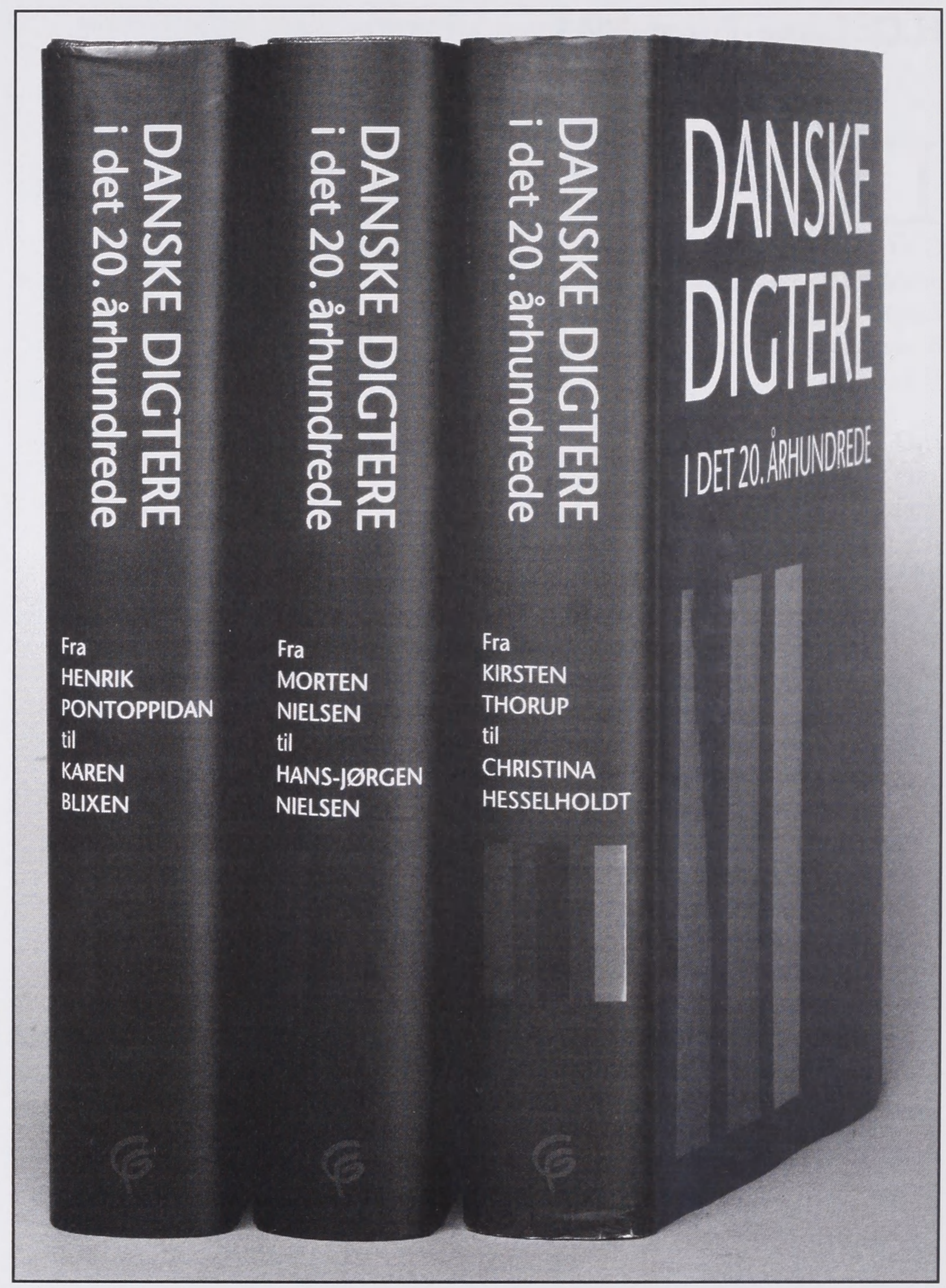

I 2003 blev forskningsformidlingsprisen givet til professor, lic.phil. Anne-Marie Mai for hovedredaktion af 4. udgaven af Danske digtere i det 20. århundrede, udgivet på Gads Forlag. Verket er en klassiker i dansk litteraturforskning og litteraturformidling. (Det Kgl. Bibliotek). 